\title{
Sociale media in en rondom de vluchtelingen- noodopvang bij Nijmegen
}

\author{
Peer Smets, Younes Younes, Marinka Dohmen, Kees Boersma en \\ Lenie Brouwer
}

MEM 92 (4): 395-420

DOI: 10.5117/MEM2017.4.SMET

\section{Abstract \\ Social media in and around the emergency shelter for refugees near Nijmegen, the Netherlands}

To cope with the limited capacity of the established reception centres during the refugee crisis of 2015, the Central Agency for the Reception of Asylum Seekers (COA) set up emergency reception centers for refugees such as Heumensoord nearby the Dutch city of Nijmegen. At the peak of the crisis, the Heumensoord centre hosted about 3,000 asylum seekers. COA's organizational approach to manage reception centers was characterized by a topdown policy. At the same time, host communities of local residents around the emergency reception center developed horizontal relations within and beyond the walls of the center, actively using available social media platforms such as Facebook. These horizontal relations enabled the development of social relations, and facilitated the exchange of goods and services. This article demonstrates the different communication strategies used by the stakeholders at Heumensoord, and how the different worlds of asylum seekers and the receiving, host communities came together. It also presents bottom-up alternatives to the top-down crisis approaches by unravelling cooperation options and the use of social media platforms that can lead to a more resilient interaction between asylum seekers and local communities.

Keywords: refugees, emergency shelter, crisis communication, social media, resilience 


\section{$1 \quad$ Inleiding}

In het najaar van 2015 kwamen vluchtelingen in groten getale via het Middellandse Zeegebied naar Europa. Dat jaar vroegen meer dan 1,2 miljoen ontheemden asiel aan in Europa, van wie er 43.093 geregistreerd werden in Nederland (VluchtelingenWerk Nederland, 2016). Europese leiders hadden moeite om gezamenlijk een oplossing te vinden voor de grote aantallen vluchtelingen die een veilig heenkomen zochten in Europa; het discours over vluchtelingen polariseerde in de Europese ontvangende landen (Polakow-Suransky, 2016). Beleidsmakers, de media, maar ook burgers spraken al snel over de 'vluchtelingencrisis' (Spindler, 2015). De crisissituatie bleek uit het vele, soms rauwe protest dat volgde op voorgenomen besluiten van (lokale) overheden om asielzoekers in grote aantallen op te vangen in noodopvangcentra. Echter, daarbij rees de vraag waar de crisis nu precies betrekking op had: was het onvrede met het relatief grote aantal asielzoekers dat in korte tijd naar Nederland kwam, en/of was het verzet tegen het, vaak ondoordachte, top-downbeleid van de lokale overheid die zonder al te veel inspraak besluiten nam over opvang van asielzoekers in noodopvanglocaties? In elk geval zag men hiervoor niet een adequate noodzaak en pakten de meeste gemeenten waar de protesten plaatsvonden het initiatief pas op toen vraagstukken over integratie de aandacht vroegen, ook in weerwil van de protesten die er plaatsvonden (Dagevos \& Odé, 2016).

In dit artikel vatten we een crisis op als een maatschappelijke situatie die uit de hand is gelopen. Hierbij heeft de perceptie van een onvoorspelbare gebeurtenis die belangrijke verwachtingen van betrokken partijen aantast een grote invloed op het functioneren van betrokken partijen en genereert negatieve uitkomsten (Coombs, 2007). Bij een crisis zien we dat het functioneren van een gemeenschap of samenleving ontwricht raakt, en overheden vaak in een beheersingsreflex schieten omdat er in hun ogen sprake is van chaos en wanorde. Dat impliceert dat we de gevolgen van een maatschappelijke crisis niet los kunnen zien van de aanpak die met de crisis is verweven. Deze thematiek bekijken we specifiek in Nijmegen, in de noodopvang Heumensoord: hoe komen asielzoekers onderling en met de ontvangende samenleving in contact en hoe zetten zij sociale media in? We willen dieper ingaan op de top-down aanpak van semi-overheidsinstellingen, de gevolgen ervan, en de (tegen)reacties daarop. We richten ons op de vraag: 'Voor welke doeleinden gebruikten verschillende deelnemende partijen in en rond de noodopvang Heumensoord sociale media en hoe draagt dat bij aan de veerkracht van deze partijen?' 
De manier waarop Europese overheden handelden tijdens de vluchtelingencrisis doet sterk denken aan een top-down crisismanagementaanpak (Hadfield \& Zwitter, 2015). Bij die aanpak is alles erop gericht de situatie onder controle te krijgen. En dat blijft niet zonder gevolgen: autoriteiten die naar controle streven, laten over het algemeen weinig ruimte voor spontane en ongestructureerde bottom-up acties (Drabek \& McEntire, 2003; Henstra, 2010). Immers, deze acties zullen in hun ogen alleen maar leiden tot nog meer chaos. De aanpak van de opvang van de vluchtelingen was daarop geen uitzondering - we zouden dan ook eerder kunnen spreken van een beleids- of institutionele crisis dan van een vluchtelingencrisis (Alink e.a., 2001).

De vraag dringt zich op waar de reflex om de crisis op deze manier aan te pakken vandaan kwam, en wat de consequenties waren voor de verschillende betrokken partijen, niet in de laatste plaats voor de asielzoekers zelf. Duidelijk is dat veel Europese landen, waaronder ook Nederland, niet waren voorbereid op de komst en opvang van zoveel asielzoekers tegelijkertijd. In Nederland werd de opvangcapaciteit van asielzoekers adhoc vergroot door het optuigen van diverse noodopvanglocaties met sobere voorzieningen, ook wel 'bed, bad en brood'-faciliteiten genoemd. In de tweede helft van 2015 hopten duizenden asielzoekers van gymzaal naar gymzaal, naar oude fabrieken, en tentenkampen. Bijna drieduizend van hen belandden begin oktober 2015 in het grootste tijdelijke tentenkamp van Nederland: Heumensoord bij Nijmegen.

Voor dit onderzoek zijn naast participerende observatie in en rond de opvanglocatie twaalf interviews afgenomen met Nijmegenaren en bewoners van Heumensoord gedurende periode november 2016 tot januari 2017. De interviews zijn in het Engels afgenomen en gebruikte quotes zijn vertaald in het Nederlands. Eén van de auteurs van dit artikel heeft vijfeneenhalve maand als asielzoeker in Heumensoord gewoond en een andere auteur is een communicatieadviseur en community manager in Nijmegen. Beiden hebben als vrijwilliger een rol gespeeld in het leggen van verbindingen tussen asielzoekers en de bewoners van Nijmegen, via sociale media. Dat maakte het mogelijk om naast het interviewmateriaal ook gebruik te maken van hun persoonlijke ervaringen en posts op Facebook. Na de periode van de noodopvang in Nijmegen hebben zij stichting Yalla opgericht (www.yallafoundation.nl), waarmee zij hun verbindende, adviserende en informerende kracht voortzetten.

In dit artikel bespreken wij allereerst de rol van crisisrespons en communicatie in theoretisch perspectief. Vervolgens zal de aandacht verschuiven naar de beschrijving van de locatie en organisatie van de noodopvang 
Heumensoord. Hierna besteden we aandacht aan de achtergrond van de dienstverlening en het hierbij betrokken personeel van COA (Centraal Orgaan Opvang Asielzoekers), de formele overheidsinstantie die verantwoordelijk is voor de opvang van asielzoekers. Tegen deze context laten we zien hoe asielzoekers binnen Heumensoord in contact komen met Nijmegenaren en de rol die sociale media hierbij spelen als communicatiemiddel. Het gebruik van sociale media roept op zich weer reacties op van COA en andere organisaties die actief waren in Heumensoord. Deze studie laat uiteindelijk zien welke rol verschillende vormen van communicatie speelden binnen en rondom de noodopvang en hoe de communicatie invloed heeft op het welzijn van de bewoners van Heumensoord.

\section{Crisisrespons en communicatie}

De 'vluchtelingencrisis' werd gekenmerkt door het onvoorspelbare karakter van de asielzoeker-(in)stroom. In een situatie waar in korte tijd veel mensen in nood moeten worden opgevangen, bieden standaardprocedures geen oplossing meer (Galindo \& Batta, 2013). De vraag is echter of het onvoorspelbare karakter van een crisis noodzakelijkerwijs moet leiden tot een chaotische situatie en vervolgens of daarbij een top-down crisisaanpak de beste remedie is. Het lijkt wel alsof in crisissituaties een wetmatigheid optreedt, die te maken heeft met de manier waarop betrokken partijen tegen de situatie aankijken. Als een situatie geframed wordt als chaos, worden pogingen ondernomen om de chaos onder controle te brengen (Holmes \& Castañeda, 2016; Van Buuren e.a., 2014; Treurniet e. a., 2015). Ongestructureerde acties om de crisis het hoofd te bieden, in dit geval door burgers en asielzoekers, zien overheden dan eerder als een aanval op de sociale orde en veroorzakers van nog meer chaos, dan als een potentiële bijdrage aan de oplossing van het probleem. En dat geldt niet alleen voor de aanpak zelf. In dit beheersperspectief wil de overheid ook de informatie over de crisis(aanpak) controleren. Immers, als de informatiestromen vanuit verschillende, deels autonome bronnen afkomstig zijn, kan er geen volledige controle plaatsvinden over de relevantie en validiteit van de inhoud.

Echter, uit onderzoek naar crisismanagement (o.a. Olsson 2014; Solnit, 2010) is gebleken dat bottom-up-acties en (begrijpelijke) informatiestromen een grote bijdrage kunnen leveren aan een efficiëntere respons op de crisissituatie. Sociale media zijn bij uitstek geschikt om bottom-up acties in gang te zetten. Niet alleen weten en voelen de getroffen personen (bewoners 
van de noodopvang) en betrokken partijen (gemeenten, maar vooral ook de ontvangende samenleving) zelf het beste welke hulp- en informatiebehoefte er is, maar ook beschikken ze over relevante kennis die benut kan worden bij de crisisaanpak. En in weerwil van een top-down crisisaanpak volgens het beheersmodel, zien we dat door de crisis getroffenen (burgers) zich zelden passief of weerloos opstellen; het tegenovergestelde is het geval (Solnit, 2010). Niet alleen waren er in Nederland verspreid protesten hoorbaar gericht tegen de opvang van asielzoekers, vaak gepaard gaande met veel media-aandacht, maar ook kwamen talloze burgerinitiatieven op gang; spontane acties van burgers die alternatieven boden voor de top-down aanpak waarbij zij direct contact zochten met de bewoners van de opvanglocaties. Net als elders in Europa, bijvoorbeeld in Engeland waar de beweging Refugees Welcome actief was (Koca, 2016), mobiliseerden ook in Nederland de burgers zich bottom-up via genetwerkte hulpacties voor en met vluchtelingen (De Beer, 2016).

Gedurende de vluchtelingencrisis werd zichtbaar dat informele informatiekanalen, met name via sociale media, een grote rol speelden bij de informatievoorziening. En dat is niet verwonderlijk: in tijden van crisis kan het gebruik van sociale media, zoals Facebook, Twitter en Instagram niet alleen dienen als extra bron van informatie, maar ook als middel om mensen te mobiliseren en tot actie aan te zetten (Meier, 2015; Palen, 2008; Schmidt e.a., nog te verschijnen).

Tijdens de vluchtelingencrisis (vooral onder de asielzoekers en de ontvangende samenleving in Nijmegen) stond een enorm aantal Facebookgebruikers met elkaar in contact. Castells (2015) zou zeggen dat dit leidt tot een netwerk van netwerken, waarbij de deelnemers geen duidelijk te identificeren coördinatiecentrum nodig hebben. Coördinatie vindt namelijk plaats door deliberatie en interacties tussen verschillende knopen in het netwerk (ibid.). Het gebruik van sociale media en mobiele technologie kan mensen verbinden en de betrokkenheid van burgers verhogen. Dit kan door vaak kritische en accurate informatie te verspreiden in de publieke sfeer door middel van ooggetuigenverslagen, alert-boodschappen, ervaringen qua evacuatie en redding, inzameling van donaties, informatieverstrekking over vrijwilligerswerk, goederen en diensten (Manso \& Manso, 2012). In andere woorden: voor de verspreiding van informatie en instructies is geen formeel leiderschap, een centraal besturingscentrum of een verticale organisatie nodig. Het zijn juist de sociale media die hier een grote rol kunnen spelen om mensen te verbinden en in te spelen op een gezamenlijke behoefte. 
Succesvolle crisiscommunicatie met behulp van sociale media vindt vaak plaats door individuele betrokkenheid van lokale deskundigen. Zij kunnen het beste de problemen op lokaal niveau inschatten, iets waar een centraal georganiseerd en geplande crisisrespons moeite mee heeft (Eriksson \& Olsson, 2016; Olsson, 2014). Hierop voortbordurend kan er onderscheid gemaakt worden tussen informatiegerichte communicatie op het handhaven van de eigen reputatie versus veerkrachtgerichte communicatie.

Een reputatiegeoriënteerde organisatie communiceert volgens Olsson (2014) top-down en reputatiegericht waarbij het management zich richt op de identiteit, reputatie en legitimiteit van de desbetreffende organisatie. Daartegenover staat een veerkrachtgerichte communicatie, waarin de ontvanger centraal staat en zelfvoorziening, netwerkvorming en vernieuwing ondersteund worden. Veerkracht verwijst naar de capaciteit van gemeenschappen om zich aan te passen aan de nieuwe situatie en een zekere stabiliteit te creëren op de lange termijn. Olsson (2014) gebruikt het begrip veerkracht om die vorm van communicatie te beschrijven, die mensen en gemeenschappen ondersteunt in processen van crisismanagement. Dit kan bijvoorbeeld door activiteiten, informatieverstrekking en zingeving te coördineren en te delen. Dit faciliteert het proces van wederopbouw en herstel, waarbij collectieve identiteiten, gedeelde normen, positieve emoties en het werken aan normaliteit en toekomstvisies bekrachtigd worden (ibid.).

De tweede dimensie van crisiscommunicatie omvat operationele versus strategische communicatie. Het hanteren van operationele communicatie draagt eraan bij dat in een bepaalde situatie alle partijen van elkaar weten wie welke taak moet uitvoeren, kortom: hoe om te gaan met de lokale situatie. Als het management van organisaties sterk gericht is op de uitvoering van taken en het gebruik van operationele communicatiemiddelen draagt het bij aan het behalen van doelen op de korte termijn. Bij strategische communicatie (goed doordacht qua strategie en aanpak) zet het management in op het behalen van doelen op de lange termijn. Deze communicatie is vaak van tevoren goed doordacht qua strategie en aanpak (Olsson, 2014).

Door de verschillende dimensies te combineren zijn vier vormen van communicatie te identificeren: operationele reputatiegerichte communicatie, operationele veerkrachtgerichte communicatie, strategische reputatiegerichte communicatie en strategische veerkrachtgerichte communicatie (zie tabel 1). Op deze vier typen van communicatie zoomen we verder in.

Ten eerste is er operationeel reputatiegerichte communicatie waarbij operationele communicatie plaatsvindt met als doel om de reputatie van 
een of meerdere betrokken organisaties te verbeteren door directe geplande communicatie of indirect door bijeffecten in ogenschouw te nemen. Een tweede vorm operationeel veerkrachtgerichte communicatie: informatiestrekking met een uitvoeringsplan gericht op zelfvoorziening gesteund door het benadrukken van een collectieve identiteit en het verstrekken van emotionele steun. Strategisch reputatiegerichte communicatie, als derde optie, verwijst naar de klassieke crisiscommunicatie waarbij het herstellen van de reputatie van desbetreffende organisatie(s) centraal staat. De laatste communicatievorm is strategisch veerkrachtgericht, waarbij de nadruk ligt op hoop, vertrouwen, betrokkenheid en coördinatie met het doel om informatie over het wat, waar, wanneer en hoe van het herstel c.q. herbouw na de crisis (Olsson, 2014).

Gecentraliseerde autoriteiten en organisaties zenden vaak hun boodschappen via traditionele (massa-) mediakanalen, hetgeen matcht met de traditionele, top-down gerichte pushcultuur. Bij een pushcultuur zenden gecentraliseerde autoriteiten en organisaties professionele informatie via massamedia zoals televisie, radio en internet. Voor een effectieve communicatie is het hier van belang om snel een gecentraliseerd en gecontroleerd systeem op te bouwen om de formulering en verzending van berichten te beheersen. Daartegenover staat een model waarbij het imago van de organisatie niet in handen ligt van enkele communicatiemanagers, maar ook mede vorm gegeven wordt door het gebruik van sociale media. Dit is mogelijk in een omgeving waar de behoeften en belangen van specifieke burgers en individuele consumenten centraal staan en waar ontvangers om informatie vragen. Dit is een pullcultuur (Olsson, 2014).

$\mathrm{Na}$ de bespreking van crisisrespons en communicatie in theoretisch perspectief vragen we aandacht voor de noodopvang Heumensoord en de communicatie rondom het opvangkamp. We zullen zien dat de spanning tussen de top-downaanpak van formele instanties en de verder reikende behoeften van veel asielzoekers, de basis vormde voor veel communicatie via social media tussen de asielzoekers en een groot deel van de lokale bewoners in Nijmegen.

Tabel 1 Ideaaltypen communicatie in crisissituaties

\begin{tabular}{c|l|l|}
\multicolumn{3}{c}{ Operationeel } \\
\cline { 2 - 4 } Reputatie-Gericht & Operationeel reputatie-gericht & Operationeel veerkracht-gericht \\
\cline { 2 - 4 } Veerkracht-Gericht \\
\cline { 2 - 3 } & Strategisch reputatie-gericht & Strategisch veerkracht-gericht \\
\cline { 2 - 3 } & \multicolumn{2}{c}{ Strategisch }
\end{tabular}

Bron: Olsson (2014, p. 117) 


\section{$3 \quad$ Heumensoord}

In deze paragraaf bespreken wij de tijdelijke noodopvanglocatie Heumensoord en geven wij een beeld van de ervaringen van haar tijdelijke bewoners. Heumensoord is normaal gesproken een natuurgebied c.q. drinkwaterwingebied nabij Nijmegen (provincie Gelderland). Nijmegen is een van de oudste Nederlandse steden met ruim 170.00o inwoners, van wie een groot deel studenten van zowel de Radboud Universiteit als de Hogeschool van Arnhem en Nijmegen (HAN). De gemeente Nijmegen heeft ten tijde van de noodopvang een links georiënteerde coalitie in de gemeenteraad van SP, GroenLinks, en de PvdA. Deze coalitie staat een sociaal, duurzaam en ondernemend Nijmegen voor ogen met aandacht voor kwetsbare groepen, een eerlijke verdeling van lasten, ruimte voor werkgelegenheid en ondernemerschap (Gemeenteraad Nijmegen, 2014). In de volksmond wordt Nijmegen door haar overwegend links georiënteerde bevolking ook wel 'Havana aan de Waal' genoemd.

Heumen is een aangrenzende gemeente die bestaat uit meerdere kleine Gelderse kernen ten zuiden van Nijmegen: Malden, Heumen, Molenhoek (grenzend aan Mook en Middelaar), Overasselt en Nederasselt. De raad telt 17 leden en bestaat uit CDA, PvdA/Groen Links, VVD en Democraten Gemeenten Heumen (https://www.heumen.nl/, 29 maart 2017).

In september 2015 gaven de gemeenten Nijmegen en Heumen toestemming aan COA om een tijdelijke noodopvang voor 3000 asielzoekers te realiseren in natuurgebied Heumensoord. Om de toegang van vrachtwagens tot het gebied mogelijk te maken, is daarna direct een tijdelijke asfaltlus door het gebied aangelegd. De bouw van het tentenkamp startte.

Op 2 oktober 2015 werd de eerste fase van noodopvang Heumensoord geopend. De opvanglocatie was toen nog in aanbouw en alleen het eerste deel opende, genaamd Green Village. Dit deel bestond uit acht grote slaaptenten verbonden door een corridor, sanitaire faciliteiten en een enorm grote hangar-achtige ruimte die dienst deed als restaurant en activiteitenhal. Dit eerste deel voor asielzoekersopvang kon ongeveer 800 personen huisvesten. De buitenruimte was op dat moment modderig - rijplaten en loopplaten ontbraken nog. Eén van de bewoners van Heumensoord zegt: 'Het ging er slecht aan toe gedurende de winter toen wij er waren, er was veel modder, water en het was koud. Ik dacht dat het niet geschikt was om mensen op te vangen, zelfs niet voor een korte periode'. In de tussentijd werd er verder gebouwd aan twee andere delen van de noodopvang; White Village en Purple Village. Begin november opende dat laatste deel. Hoewel in die tijd de intentie misschien niet zo was, of de verwachting: de meeste 
bewoners hebben bijna een half jaar lang in deze noodopvangsituatie doorgebracht, zonder enige kennis van wanneer zij precies hun asielprocedure konden beginnen. Deze onzekerheid droeg enorm bij aan de stress van de bewoners van Heumensoord. Een medewerker van Vluchtelingenwerk reflecteert: 'Ik heb nog nooit zoveel stress bij elkaar gezien en zoveel crisismoment bij elkaar beleefd op persoonlijk, menselijk niveau'. Hij bedoelde: mensen die flipten, mensen die wanhopig waren.

Daarnaast leefden de asielzoekers dicht op elkaar. Elke slaaptent, met 96 bewoners, was verdeeld met dunne tussenwanden in 12 slaapgebieden zonder afsluitbare deur. Elk slaapgebied huisvestte acht asielzoekers. Elk individu kreeg een vaste slaapplek toegewezen: een bed dat onderdeel was van een stapelbed en een kleine, compacte metalen locker om eigendommen in op te bergen. In elk slaapgebied bevonden zich acht stopcontacten, geconcentreerd op een plek. Vooral de bewoners wiens bed ver van deze stopcontacten stond, waren hier niet blij mee. Het opladen van telefoons vond bij voorkeur plaats zonder het onderbreken van het telefoongebruik. Verlengsnoeren waren verboden vanwege mogelijk brandgevaar.

Per zo'n 800 bewoners bestonden de sanitaire voorzieningen uit 14 toiletten voor mannen, 14 toiletten voor vrouwen en 14 douches. Deze voorzieningen, die ook voor campings en festivals gebruikt worden, moesten ecologisch - dus parfumloos - gereinigd worden om het grondwater in Heumensoord te beschermen. Dat had invloed op de heersende geur bij deze faciliteiten. Later opende COA in elk deel van Heumensoord een tent die dienst deed als recreatieruimte en/of restaurant. Tijdens de opstart van de opvanglocatie Heumensoord waren er ongeveer 35 stopcontacten en beperkte wifi-voorzieningen in de grote activiteitenhal. Bij de stopcontacten was het meestal erg druk, omdat bewoners hun mobieltjes in het vizier wilden blijven houden tijdens het opladen, om diefstal te voorkomen. De mobiele telefoons vormden voor hen de poort naar de buitenwereld en waren dus van levensbelang.

De activiteitenruimten werden ook gebruikt voor kleine optredens, kinderactiviteiten, tv-kijken, pingpongen, badmintonnen, lezen en praten met andere bewoners. In de restaurantruimten werd drie keer per dag binnen een strak tijdschema een maaltijd (twee broodmaaltijden en een warme magnetronmaaltijd) verstrekt. Ook was er in elk deel van Heumensoord een ruimte met wasmachines waar bewoners zelf hun was konden doen.

In de slaapruimten verbleven bewoners met verschillende achtergronden. Zo kon het zijn dat een groep die een slaapkamer deelde, verschilde in sekse, religie, etniciteit en leeftijd, maar ook waren er gezinnen met kinderen en alleenstaanden. De bedden werden centraal toebedeeld. Deze 
diversiteit aan kamergenoten leverde bij veel bewoners spanningen op. Een van de bewoners van Heumensoord vertelt:

Verschillende culturen zijn gemengd, iemand wil roken, een wil muziek luisteren, weer een ander wil bidden, een ander wil drinken, enzovoorts. Dagelijks zijn er gevechten en geschreeuw over allerlei zaken. Als er gevechten zijn tussen twee personen is de oplossing van COA om een persoon naar een kamer ernaast te plaatsen, maar ze blijven elkaar tegenkomen. De muren van de kamers zijn van karton. Soms wordt iemand naar een andere opvanglocatie gezonden (...). Ik kan een, twee maanden wachten, maar uiteindelijk zal ik ontploffen. Mijn vrouw huilt, en ook de kinderen soms wanneer zij de kamer moeten verlaten. De kinderen spelen buiten. Ik kan niet alles uitleggen. Het was soms een groot probleem voor me als ik in de kamer zat en hoorde dat in aangrenzende of tegenoverliggende kamers mensen slechte woorden gebruiken, of de acties tussen man en vrouw. Je hoort alles wat ze doen [geslachtsverkeer]. (...) Ik was in het restaurant, mijn zoon ging naar de bewaking (...) en vertelde hem dat onze buurman een vrouw aan het vermoorden was. De bewakingsbeambte kwam snel. Daar was de vrouw en hij hoorde lawaai. De bewaker dacht dat de man de vrouw aan het vermoorden was. Hij opende het gordijn, ging naar binnen en trof ze daar aan. De man was ontdaan en vocht met de bewaker.

Overlast kon ertoe leiden dat bewoners wilden ruilen van kamer en/of bed, maar dat was alleen mogelijk in specifieke gevallen met toestemming van COA. In de volgende paragraaf zal aandacht besteed worden aan de dienstverlening van COA.

\section{Dienstverlening en COA-personeel}

COA, dat onder de verantwoordelijkheid van het Ministerie van Veiligheid en Justitie valt, was verantwoordelijk voor de bewoners en hun veiligheid en liet ketenpartners of andere organisaties na de beginperiode toe binnen de locatie om diensten te verlenen, zoals het Rode Kruis, VluchtelingenWerk Nederland (VWN), Gemeentelijke Gezondheidsdienst (GGD) en Gezondheidscentrum Asielzoekers (GCA). Denk aan diensten ten aanzien van juridische bijstand, basisgezondheidszorg, infectieziektenpreventie en voedselveiligheid. De Immigratie- en Naturalisatiedienst (IND), de organisatie die zorg draagt voor de asielzoekersprocedure, was buiten enkele voorlichtingsbijeenkomsten zelf niet aanwezig in deze noodopvang. 
De eerste groep bewoners in Green Village verbleef nog in Heumensoord op het moment dat hun asielprocedure startte. Om de procedure te doorlopen verhuisden veel bewoners van Heumensoord dus niet naar een COAprocedurelocatie, maar werden zij elke dag voor een kleine week met bussen naar de desbetreffende IND-verhoorlocaties gebracht. Daar werden de interviews gehouden die onderdeel uitmaakten van de asielprocedure.

In oktober 2016 kon niemand nog inschatten hoe lang de hevige toestroom van asielzoekers zou doorgaan en hoe lang de bewoners zouden moeten wachten op hun asielprocedure. De formele organisaties binnen de opvanglocatie, zoals COA, VluchtelingenWerk, GCA (artsen/verpleegkundigen) en gemeenten waren allen gericht op een specifiek omschreven deeltaak en dus op verschillende afgebakende manieren actief binnen of buiten de noodopvang. Dit was vaak noodzakelijk om de aankomst, verblijf en doorstroom van vluchtelingen in goede banen te leiden. Veiligheid van iedereen stond hierbij centraal. Maar het frustreerde ook veel mensen, omdat er naar taken gekeken werd, niet naar mensen.

De manieren waarop medewerkers van de organisaties of de organisaties zelf communiceerden met de asielzoeker verschilden erg en leken niet altijd het doel te bereiken om de mensen gerust te stellen en met intercultureel afgestemde communicatie in te spelen op behoeften. Nogal wat asielzoekers waren ontevreden met de aangeboden communicatie.

D: Ze vertelden ons niets over waar we naartoe zouden gaan. We kregen een vel papier, zoals je altijd krijgt bij een transfer. Daarop stond Heumensoord. Maar niemand wist waar of wat dat was. Sommigen van de jongens met een mobiele telefoon gingen het googelen, dus toen wisten we bij welke stad het in de buurt was: Nijmegen. Ik had zelf toen geen telefoon. (...) En ik hoopte dat alles afgerond zou zijn binnen een paar maanden, drie of vier maximaal. In mijn hoofd had ik het hele proces al klaar in drie-vier maanden.

I: Heeft iemand je verteld hoe lang je daar zou moeten blijven?

D: Nee, maar ik had drie-vier maanden in mijn hoofd voor het gehele proces. Ik wist echt niet dat we in een noodopvang zaten in Heumensoord en niemand vertelde ons hoe lang we hier zouden blijven. (...) Voor zover ik het weet, het was een echt grote plek en ik wist niet het verschil tussen een woonbegeleider en het COA-management. Alle mensen binnen COA waren hetzelfde. Wat ik weet is dat er een zekere druk voelbaar was, zeker op sommige medewerkers, omdat ze in tweestrijd leken tussen de COA-regels en vriendschap sluiten met ons. Ik weet dat er vrouwen waren die zelfs ontslagen waren. De strenge regels maakte het voor hen niet mogelijk flexibel te zijn. Aan de andere kant begonnen ze met ons vriendschap te sluiten en met ons te praten. 
Hier zien we dat er een spanningsveld zit tussen het omgaan met de regels en het meer persoonlijk omgaan met de asielzoekers. Er zijn communicatieproblemen waaruit blijkt dat de asielzoekers niet altijd op de hoogte zijn van het aanbod van activiteiten. De Nederlandse gewoonte om aankondigingen op te hangen gaat ervan uit dat dat afdoende is om drieduizend asielzoekers in te lichten over activiteiten. Daarentegen verwachten asielzoekers vaak dat ze aangesproken worden als er activiteiten plaatsvinden. De centraal gestuurde top-down gerichte communicatie bereikt niet altijd de hele doelgroep adequaat. Bovendien vindt er op deze wijze weinig afstemming met de asielzoekers en hun verschillende culturele patronen.

Een groot deel van de COA-staf bestond uit jonge mensen, onder wie veel pas-afgestudeerde sociaal werkers die regelmatig de ervaring leken te missen om te werken met een groot aantal asielzoekers, en al helemaal niet waren voorbereid op een dergelijke noodsituatie. Een COA-beambte vertelt dat het niet gemakkelijk is om regels en protocollen te combineren met een humane benadering. De regels geven houvast voor het COA-personeel en een deel van de vluchtelingen, maar het is niet altijd mogelijk om met een groot aantal asielzoekers (300o in Heumensoord) hun persoonlijke omstandigheden mee te nemen. Ze vervolgt haar verhaal door aan te geven dat ze duidelijke richtlijnen nodig heeft om met de lokale situatie om te gaan:

Als je de regels goed kent is het makkelijker om ze enigszins flexibel en op een respectvolle manier toe te passen. Je moet wel weten waarom die regels er zijn. Als er collega's zijn die het hoe en waarom van de regels niet kennen en de regels aanpassen, kan er een moeilijke situatie ontstaan.

Op de vraag of regels wel flexibel toegepast mogen worden antwoordt ze:

Of pas ze niet flexibel toe. Soms is het houvast voor het personeel. Voor hen moet het werk duidelijk zijn. Niet iedereen is geknipt voor dit werk. Ik denk dat de helft van de mensen in Heumensoord niet geschikt was voor dit werk. Omdat we veel mensen nodig hadden... Sommige waren geobsedeerd door de regels, terwijl anderen de teugels geheel laten vieren. Dan creëer je een vreemde sfeer. Dat merk je... en natuurlijk merken de bewoners dat ook. Ik zeg niet dat deze mensen (vluchtelingen) kinderen zijn, maar ze zijn als mijn kinderen. Als ik niet duidelijk ben, gaan ze alle kanten op.

Het personeel volgde de COA-omgangs- en werkprotocollen voor het verrichten van het werk. Gedragsregel 1 vermeldt: 'Het is voor de medewerkers niet toegestaan om affectieve/intieme relaties aan te gaan en/of te 
onderhouden met bewoners' (COA, 2016). De impact hiervan is dat medewerkers en vrijwilligers bij hun werk doorgaans persoonlijk contact mogelijk met tegenzin uit de weg gaan. Het samen drinken van een kop koffie is vaak al te veel. Als het om sociale media gaat wordt in de COA-gedragscode vermeld:

Steeds meer mensen profileren zich op internet op diverse forums en netwerken (Hyves, Facebook, LinkedIn, e.d.). Binnen de profielen wordt vaak een combinatie aan informatie verwerkt die zowel privé als zakelijk is. Wij zijn ons ervan bewust dat de COA-organisatie in zo'n geval gekoppeld wordt aan onze persoonlijke overtuigingen en leefstijl (COA, 2016, p. 6).

Er is een discrepantie tussen het COA-regime dat controle over de crisis wil hebben, en de asielzoekers die onderling via sociale media verbanden leggen en zo met elkaar en de buitenwereld communiceren. Vluchtelingen laten zien hoe ontevreden ze zijn over het regime en hoe weinig zij zich gesteund voelen bij hun integratieproces. Eén van de vluchtelingen zegt hierover:

We hebben hier een nieuw leven, een heel ander leven, cultuur, taal en system. En COA werkt erg hard om ons weg te houden van ieder idee daarover. Alles wat ze kunnen doen zijn de woorden: 'We weten het niet', 'Het is niet onze baan' (bewoner van Heumensoord, bron: 20-06-2016, Facebookgroep Refugees in Netherlands Nijmegen).

Op een meer abstracte manier kan de manier waarop COA asielzoekers opvangt worden bekritiseerd door wat Goffman (2007) een 'totale institutie' noemt (cf. Geuijen, 1998). Binnen een totale institutie worden menselijke behoeften vervuld door middel van bureaucratische controle van een grote groep mensen op een onpersoonlijke en rationale manier (Goffman, 2007). De meeste activiteiten zoals eten, slapen, vrijetijdsbesteding en (vrijwilligers)werk vinden plaats binnen de muren van een totale institutie en apart van diegenen die niet bij die institutie horen. Sociale interactie met de buitenwereld is beperkt of zelfs geheel afwezig. Verveling leidt vaak ertoe dat bewoners problemen ervaren in intellectueel en emotioneel welzijn. Opvallend is het dat de bewoners gescheiden zijn van de staf, waardoor er weinig contact en interactie is tussen beide groepen.

In de praktijk zien we dat COA-medewerkers en -vrijwilligers de veilige weg bewandelen qua gebruik van sociale media en het stimuleren van contact met de buitenwereld met hun activiteiten. Een van vluchtelingen zegt 
over de COA-protocollen dat COA-personeel zich niet anders mag gedragen, dat wil zeggen anders dan de regels voorschrijven. Al met al waren er zowel vluchtelingen als professionals rondom de opvang die buiten de protocollen om vertelden dat niet alles even goed ging. Zij zochten betrouwbare partners buiten de noodopvang als ze zich te beperkt voelden door de COA-gedragsregels.

Dag en nacht manageden we de online platforms waar gediscussieerd werd; jezelf laten zien, vragen stellen, gesprekken voeren en uitreiken naar de ander. Wij als online groepsleiders (admins) werden bijna gezien als bemiddelaars. In persoonlijke boodschappen krijgen we vragen over hoe men regels moet interpreteren, of waar naartoe men moest gaan voor hulp. Niet alleen bewoners en vrijwilligers maar ook professionals. Bijvoorbeeld een GCA-verpleegster die ons vroeg om met spoed kleren voor een vluchteling te regelen. Een kledingbank was gesitueerd naast haar kantoor, maar ze durfde het niet aan om verder te handelen buiten wat haar precieze taakomschrijving aangeeft. Een COApersoneelslid vroeg ons om iemand die alleen is te helpen en verbindingen te leggen. Iemand van het VluchtelingenWerk en de GGD hielp me en verstrekte me de juiste informatie om online te zetten, maar zij waren erg terughoudend en durfden niet of mochten niet zelf persoonlijk zichtbaar bijdragen aan de Faceboookgroep. Dat dus allemaal via de 'achterdeur' (admin van de Facebookgroep Refugees in Netherlands Nijmegen).

\section{Contact tussen ontvangende samenleving en de asielzoekers}

Vanaf de eerste dag heetten bewoners uit Nijmegen de vluchtelingen welkom. De Facebookpagina Welcome to Nijmegen verrees al een aantal weken voor de komst, en werd opgericht en gemanaged door een sociaal werker en een communicatieadviseur (uit eigen initiatief). Onder meer aangejaagd door hen, startten veel Nijmegenaren met de voorbereidingen op de komst van de vluchtelingen. Tientallen Nijmegenaren toonden welkomstboodschappen bij de ingang van de noodopvang toen de vluchtelingen arriveerden begin oktober, hoewel dit afgeraden werd door instanties. Direct daarna startte een bewoner van Heumensoord de Facebookgroep Refugees in Netherlands Nijmegen en beide partijen gingen samenwerken op dit forum om verbindingen te kunnen ondersteunen. Het werd een plek waarop alle groepsleden konden posten en reageren op elkaar. 
Mede door oproepen via de Facebookpagina Welcome to the Netherlands Nijmegen boden al snel bijna tweeduizend vrijwilligers uit de ontvangende samenleving hun diensten aan bij Steun- en Informatie Punt (STIP)-Noodopvang, een in het leven geroepen coördinatiepunt voor vrijwilligerswerk op Heumensoord. Bij STIP-noodopvang was een groep vrijwilligerscoördinatoren actief die formeel in contact stond met het COA en het aanbod van vrijwilligers moest coördineren. Het aanbod aan hulp was echter niet altijd passend ten aanzien van de voorwaardes die COA hanteerde, en het aanbod bleek al snel te overweldigend om allemaal via deze hub aan te komen bij de mensen die het toekwam.

STIP-noodopvang stond in contact met de activiteitencoördinator van COA. Door COA goedgekeurde activiteiten moesten aan bepaalde regels voldoen. Gelijkwaardig behandelen (geen jaloezie opwekken) was daar één van. En veilig handelen. Maar gezien de grootte van de opvanglocatie werd heel veel aanbod daardoor als niet passend ervaren. Zo werden 1000 drinkflessen niet uitgedeeld omdat het er geen 3000 waren. En het plaatsvinden of verstrekken moest niet te veel problemen opleveren of personeelscapaciteit kosten. Een ander voorbeeld is dat het doneren van speelgoed niet werd toegestaan. Er ontstonden al snel vechtpartijen tussen kinderen die jaloers waren op het speeltje van een ander. Alleen voor elk kind hetzelfde kleine en veilige cadeautje (ongeacht leeftijd, et cetera) was mogelijk tijdens een Sinterklaasviering georganiseerd door vrijwilligers. De gedragsregels beschrijven bovendien ook dat COA zich continu bewust is van het politieke klimaat en ook daar rekening mee houdt in het werk. Daardoor zouden zij ook niet toestaan dat al te veel gepamper plaatsvond.

Wat betreft vrijwilligers moest een COA-medewerkster snel beslissen of iemand als vrijwilliger geschikt was of niet, en ze voelde zich verantwoordelijk om de COA-regels daarbij toe te passen - waarbij veiligheid voorop staat. Samen met een vrijwilligster uit Nijmegen heeft de COAmedewerkster onder andere schaakactiviteiten opgezet, waarbij zij de vrijwilligster aanraadde om Facebook te gebruiken voor specifieke oproepen in plaats van de formeel opgetuigde samenwerking met STIP. Via Facebook werden twintig vrijwilligers voor het schaken gevonden. Op de vraag of de COA-medewerkster ook sociale media gebruikte als ze specifieke hulp nodig had, antwoordde zij:

Die mocht ik niet gebruiken. Ik dacht dat ik een Facebookpagina kon maken voor intern gebruik (...) maar die werd geblokkeerd. Ik kon mijn account niet gebruiken. We konden er niets aan doen. Maar we hingen stomme affiches op. Dat werkt natuurlijk niet. Je hebt mensen nodig die het doorvertellen. Maar 
we deden wat we konden. Ik heb gebruikgemaakt van een vrijwilligster die wervingsteksten voor alles maakte. Het enige wat ik kon doen was het aanmaken van een mailadres voor de bewoners (...), rondlopen en mensen erover vertellen.

We zien hier dat bij de COA-medewerkster een top-down manier van aankondigen centraal staat, maar dat zij het liever anders wil doen. De COAmedewerkster maakt gebruik van een vrijwilligster uit Nijmegen om oproepen op sociale media te kunnen plaatsen en zo toch de kracht van sociale media te benutten.

Al met al bleek in de praktijk dat het officieel geaccordeerde aanbod van activiteiten en diensten op locatie pas na weken flink op gang kwam. Bovendien was er bij de asielzoekers een grotere of meer diverse behoefte aan contact, activiteiten en diensten, vooral buiten de locatie. Sommige burgers die buiten de reguliere kanalen hun diensten wilden aanbieden, of in contact wilden komen met nieuwkomers, zochten de locatie zelf op of probeerden contact te leggen met bewoners via de Facebookgroep Refugees in Netherlands Nijmegen.

De opvanglocatie mochten zij echter niet betreden zonder persoonlijke uitnodiging van de bewoners zelf - en ook mochten goederen niet uitgedeeld worden bij de ingang of op de locatie. Na ongeveer een maand werd deze bezoekersregeling opengesteld of gecommuniceerd: vanaf dat moment konden asielzoekers bezoekers uitnodigen. Bezoekers moesten zich dan registreren bij de informatiebalie bij de hoofdingang en de bewoner bleef te allen tijde verantwoordelijk voor zijn of haar bezoeker. COA communiceerde deze bezoekersregeling niet actief in Nijmegen, maar deze was wel meegedeeld aan bewoners tijdens bijeenkomsten en op een informele manier.

Toen de noodopvang geopend werd, konden bewoners uit Nijmegen en dienstverleners het bos inrijden tot aan de ingang van de noodopvang. $\mathrm{Na}$ de aanslagen in Parijs in 2015 (Bataclan) zorgde COA voor een slagboom aan het begin van de asfaltweg, direct na de parkeerplaats. Daardoor waren zowel bewoners als vrijwilligers gedwongen om de lange weg door het bos naar de ingang van de opvanglocatie te voet of per fiets af te leggen. Dat was vooral voor families met kleine kinderen een (te) lange wandeling. Denk bijvoorbeeld aan een familie met oma en kleine kinderen, die na een avond uit eten bij een Nijmeegse familie deze afstand in een herfststorm met jonge kinderen nog moest afleggen.

Deze weg, en met name de parkeerplaats aan het uiteinde nabij Nijmegen, werd al snel een druk ontmoetingspunt. Bewoners uit Nijmegen 
en asielzoekers ontmoetten elkaar vaak hier. De parkeerplaats nabij de slagboom werd een plaats waar vrijwilligers en vluchtelingen goederen uitwisselden of afspraken via sociale media. Vaak was het een drukke bedoening, soms zelfs met bijna een grimmige sfeer wanneer veel personen de goederen tegelijk wilden claimen. Dat was bijvoorbeeld het geval toen een vrouwelijke vrijwilligster met een auto vol koffers aankwam bij Heumensoord. Ze werd angstig toen vele mensen naar haar auto renden en binnen een paar seconden de wagen geopend hadden. De mensen vochten en in een mum van tijd was de auto leeg.

Veel Nijmegenaren die buiten de reguliere en officiële kanalen in contact wilden komen met bewoners van Heumensoord, maakten daarvoor gebruik van de Facebookgroep Refugees in the Netherlands Nijmegen die als doel had om dankbaarheid te tonen aan Nederland/Nijmegen, elkaar te helpen met het oplossen van kleine problemen en contact te leggen om een start te maken om deel uit te maken van de Nederlandse samenleving (integratie). Deze Facebookgroep werd opgericht op de eerste dag van de noodopvang door een 33-jarige Syriër die zelf in Heumensoord verbleef. Hij wilde een instrument maken dat de Nederlandse samenleving bereikt en waarop vluchtelingen hun waardering voor de Nederlandse samenleving konden uitdragen. De andere twee oprichters en professionals van Welcome to Nijmegen werkten vanaf dag één mee en zorgden voor een overdracht van Nijmegenaren richting de Facebookgroep, vanaf de Facebookpagina Welcome to Nijmegen. Alleen zo was een inclusieve samenleving mogelijk waarbij nieuwkomers en Nijmegenaren elkaar konden vinden.

Het werd al snel een zeer veelgebruikt platform. Dagelijks werd er gepost over activiteiten, benodigdheden, en contact gezocht door bewoners van Heumensoord, of locals - met als doel op informele wijze tot elkaar te komen. In juni 2016, nadat Heumensoord sloot, had de Facebookgroep Refugees in the Netherlands Nijmegen 675 o deelnemers, een gemengde groep van vluchtelingen en lokale bewoners. Nog altijd zijn zowel Nijmegenaren als statushouders en AZC-bewoners actief op deze Facebookcommunity met als doel een inclusieve samenleving te bereiken en laagdrempelige hulp en contact mogelijk te maken.

\section{Communicatie en het gebruik van sociale media}

Vanaf de eerste dag dat Heumensoord opende en de groep startte, communiceerden de lokale bevolking en asielzoekers met elkaar. De bewoners kregen geen leefgeld in de noodopvang en vroegen soms om dingen die ze 
nodig hadden zoals kinderwagens, kleren, warme jassen en waterkokers. Enkele voorbeelden van dergelijke verzoeken staan hieronder letterlijk weergegeven; 'Hello, evry one can you help me please? I need bike lock, and I need air blower for bike because I get geaft bik but have no air in the tier. Thanks.'; 'Good morning everyone Please I want an umbrella and bik. It is very necessary thanks all.'

Bewoners nodigden nieuwkomers uit op de koffie, om te eten, of om samen naar een speeltuin te gaan. Van twee kanten werd getracht om met elkaar in contact te komen. De groepsadmins binnen en buiten de locatie probeerden deze contacten te stimuleren door advies en aanmoediging. Vluchtelingen die Engels spraken vormden daarbij ook een brugfunctie zowel interpersoonlijk als online - tussen de vluchtelingen en de lokale bevolking. Veel meningen werden uitgewisseld, hetgeen soms ook leidde tot misverstanden en conflicten. Ondanks deze wrijvingen werd er gezocht naar manieren waarop samengewerkt kon worden. Dit was ook reden voor de administrators van de groep om te starten met een aanverwante, Nederlandstalige Facebookgroep voor Nederlandstalige vrijwilligers genaamd Independent Volunteers Nijmegen en de website www.yallafoundation.nl waarop de veel gestelde vragen beantwoord werden in het Engels. De stichting Yalla streeft naar een insluitende samenleving (on- en offline) met minder sociale instabiliteit. Yalla stimuleert gekanteld werken met asielzoekers en statushouders die vaak geïsoleerd leven in opvanglocaties. Hun informatiebehoefte kan vaak direct bevredigd worden online, zonder de afhankelijkheid van de formele organisaties rondom hen. In de ogen van de stichting is het bouwen van een positief en divers sociaal netwerk noodzakelijk voor succesvolle integratie in de Nederlandse samenleving.

Op de vrijwilligerscommunity Independent Volunteers Nijmegen werden informatie en ervaringen uitgewisseld en uitdagingen geduid, die het begrip rondom de opvang, asielprocedure en communicatie met nieuwkomers vergrootten. COA mocht geen onderscheid maken tussen bewoners en verspreidde niet zomaar goederen, behalve als deze voor iedereen in dezelfde kwaliteit beschikbaar waren en de uitgifte geen probleem vormde. Dat was natuurlijk voor 3000 bewoners lang niet altijd mogelijk. Sommige Engelssprekende vluchtelingen probeerden samen met vrijwilligers op een zo eerlijk mogelijke manier de behoeften van bewoners helder te krijgen en aanlevering van gedoneerde goederen of uitnodigingen zodanig te organiseren dat deze aankwamen bij de vluchtelingen die ze ook echt nodig hadden. Op deze manier werden al snel honderden kinderwagens gedoneerd en overgedragen in de bossen rondom Heumensoord, uitnodigingen verstuurd, maar ook fietsen, kleren, schoenen, en meer uitgewisseld. Soms 
in overvloed. Het was een ondoenlijke uitdaging om deze goederen te verdelen onder de 3000 vluchtelingen binnen de noodopvang. Onderstaande post op Facebook laten zien dat dit niet altijd gemakkelijk gaat.

Ik kom net van Heumensoord af en ondervind dat er een aantal mensen meerdere spullen hebben en verzamelen, zoals buggy's waar anderen juist helemaal niets hebben. Vaak omdat ze geen Engels spreken of bescheiden zijn. Misschien slim om dit af te stemmen met R.A. [bewoner Heumensoord]. Hij heeft het op zich genomen om zo goed mogelijk overzicht te houden van welke familie wat nodig heeft, aangezien vele geen Engels spreken of toegang hebben tot social media. Alle hulp is welkom. (...) Hulp en delen is good karma;-) (bewoner Nijmegen en onafhankelijke vrijwilliger, o1-12-2015. Bron: Facebook Refugees in Netherlands Nijmegen).

Een geïnterviewde asielzoeker vertelt hoe er gezocht wordt naar oplossingen:

We gingen met acht personen naar de stad. We liepen op een weg parallel aan Heumensoord en we hadden ongeveer 20 zakken met kleren en schoenen bij ons. Ik heb ze in mijn kamer gezet, in het slaapgedeelte en gaf aan dat de mensen konden komen, maar na twee uur ontstond een groot conflict tussen een vrouw uit Eritrea en enkele Syriërs. Het was een les voor ons om dit niet nog een keer te doen. We voelden ons verantwoordelijk. (...) We vroegen vrijwilligers die wilden helpen bij de verdeling van spullen en legden een-op-een verbindingen met mensen die iets nodig hebben, en organiseren de overdracht van goederen buiten de poorten van COA (bewoner Heumensoord).

Het zien van de effecten van connecties online zoals foto's van diners en dankbare berichten van nieuwkomers werkte motiverend voor groepsleden om in te stappen en contact aan te gaan.

In het begin liepen veel vluchtelingen en vrijwilligers tegen het COAsysteem aan. Ze waren niet gewend aan het lokale voedsel en de gang van zaken. Ze snapten niet waarom de Nederlanders 's ochtends en 's middags brood en kaas aten en zij dat ook moesten eten. Bovendien snapten ze niet waarom de dokters in hun ogen alleen maar paracetamol gaven, wat een huisarts was, wat het verschil of de taakverdeling was tussen organisaties, zoals COA en IND, wat wel mocht en niet mocht. Facebook werd gebruikt om klachten over de leefomstandigheden te uiten, maar ook informatie met elkaar te delen en elkaar te steunen. Bovendien probeerden vluchtelingen er een beeld te schetsen met tekst en beeld van het leven binnen de noodopvang. 
Hier zien we dat er een kloof is tussen verwachtingen en de lokale realiteit. Om hier zicht op te krijgen maakten de asielzoekers gebruik van Facebook door leden van de groep te volgen of zelf boodschappen te posten. Sommige zochten via de community naar beroepsgenoten in de Nederlandse samenleving.

Uit de interviews blijkt dat de vluchtelingen geen idee hadden van wat er te verwachten was tijdens hun verblijf in Heumensoord. Dit ging ook op voor de vrijwilligers die niet wisten hoe lang de bewoners er zouden blijven, wat do's en don'ts waren, hoe ze binnen zouden kunnen en mogen komen en wat de behoeften van de vluchtelingen waren.

De vluchtelingen hadden echter bijna allemaal een smartphone, die gebruikt werd om in contact te blijven met de wereld tijdens hun vlucht. Door het gebruik van sociale media - meer specifiek Facebook en WhatsApp verliep communicatie gemakkelijker en sneller, en dat werd doorgezet tijdens hun verblijf in Heumensoord. Zodra asielzoekers in Heumensoord ontdekten dat de Facebookgroep bestond, maakten ze er gebruik van. Facebook werd gezien als een mogelijkheid om op een gemakkelijkere manier te communiceren met Nederlanders.

T: De sleutel om te communiceren met alle mensen. Deze groep kan een ijsberg die tussen vluchtelingen en Nederlandse burgers breken. Deze sleutel stelt ons in staat om op een eenvoudige manier te communiceren. Misschien is iemand verlegen en kan geen contact leggen met een Nederlander, maar via Facebook en de groep kan hij het wel.

I: Is het makkelijker?

T: Ja als ik op een bepaald moment een vrijwilliger in Heumensoord zie, kan ik niet direct erop afstappen en zeggen: 'Hoi ik ben een Syrische tandarts en ik werk hier'. Dat kan ik niet. Misschien zegt hij dan: 'Ok. dat interesseert me niet'. Maar op de Facebookgroep vind je wel enige mensen die interesse vertonen in deze situatie (bewoner Heumensoord).

Het grote aantal leden van de Facebookgroepen en de zichtbaarheid van het effect van contact - zowel bij de vluchtelingen als de lokale bevolking zorgden ervoor dat de interactie tussen mensen steeds groter werd. Het creëerde zelfs een basis voor niet-Engelssprekende vluchtelingen die zich veilig genoeg voelden om in hun moedertaal te posten.

Lezers van de berichten gebruiken daarvoor automatische software (Google Translate) om de boodschap in essentie te vertalen, of bewoners worden geholpen door vrienden of bezoekers om hun noden kenbaar te maken. Al met al lijkt het erop dat het netwerk uitgebreid wordt en zelfs geleid heeft tot het vinden van sociale en professionele maatjes. 
Goedendag Nijmegen. Ik ben erg blij dat... [Heb] goede herinneringen aan de mensen van Nijmegen. Jullie waren zo vriendelijk en gastvrij. Voor bijna zes

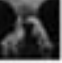

Decenter 2.2015

\section{\# Thanks Nederland}

Min naam $x x x x \times x x x x$ 'van Syrie en min woorden dat is de meerderheid We gingen uit van $S y n$ í op zoek naar alleen de veligheid en kwam niet voor het geld of voedsel of bleding in het land van de wede Nederland we voeiden ons velig en wat we zien van het Nederlandse volk meer prachtig om te zien dat je ales voor ons comfort te doen en we zin dankbaar en dank-je van ons hart. $\mathrm{Ze}$ zin roeren tot problemen voor het eten of anders worden ze niet aleen zichzelf vertegenwoordigen op of Dank herhalen voor alle goede mensen als vifiviliger voor ons in ale gebieden en een gimlach in de ogen van onze kinderen in een permanente glimlach mooie ogen te trebken en geef ons een positieve zaak We betreuren al roeren tot problemen. \# Daniaj land en de mensen van Nederland.

Sory voor slechte vertaing, het schriven
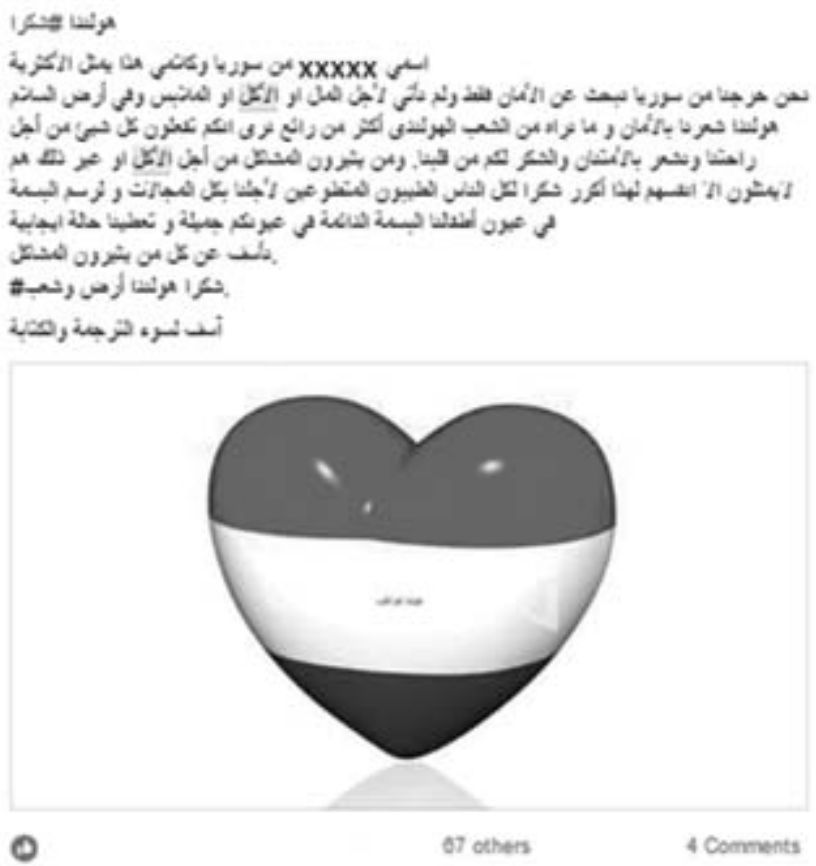

ib tike Comment

Thank you very much for your kind words. Do not be soery for (snul) probiems that oocur: ve are all human beings with enotions, ve are not machines! I an very grateful that you are bere and that we are able to help you. You belp us to besome better humans as nell 
maanden hadden we een goede tijd hier. Ik herinner me jullie vriendschap de rest van mijn leven. Ik apprecieer het zeer dat jullie goed werk deden, vooral COA. Ik ben blij dat ik nu veel Nederlandse vrienden heb. (bewoner Heumensoord, bron: Facebookgroep Refugees in Netherlands Nijmegen, 23-042016, vertaald uit het Engels)

In andere gevallen zien we dezelfde boodschap in meerdere talen op Facebook geplaatst wordt. Zie voor een voorbeeld figuur 1.

\section{$7 \quad$ Conclusie}

In dit artikel hebben we laten zien dat formele en informele (overheids)organisaties op verschillende manieren omgaan met de 'vluchtelingencrisis'. In de noodopvang Heumensoord domineert een hiërarchische organisatie met een regime dat veiligheid vooropstelt om via die weg weer controle op de crisis te krijgen. In dit verband verdedigt het COA zijn reputatie op een strategische wijze: via de aanpak van de klassieke crisiscommunicatie. De aanpak is sterk top-down georiënteerd, waarbij protocollen worden gebruikt om het gedrag van eigen personeel en vrijwilligers te sturen. Eigen initiatief van de COA-staf werd in eerste instantie gezien als een aanval op de sociale orde die potentieel nog meer chaos veroorzaakt. Verzonden boodschappen (bijvoorbeeld affiches over vrijwilligerswerk of activiteiten in Heumensoord) begrepen de ontvangers, in dit geval de asielzoekers echter niet altijd. In praktische zin wierpen de Nederlandse taal en gebruiken een drempel op voor deelname. Bovendien was de manier van communiceren vaak erg directief: je moet dit doen en je kunt dit niet doen. De pushcultuur en de top-down aanpak was hier duidelijk zichtbaar. Aan de ene kant was er het voordeel van een duidelijke controle op boodschappen die verstuurd werden in een setting met een grote hoeveelheid asielzoekers die onder stress leven met vele lotgenoten.

Echter, de top-down aanpak hield aan de andere kant geen rekening met spontaan opkomende acties van vluchtelingen en burgers: tussen de lokaal ontvangende samenleving - Nijmegenaren - en de vluchtelingen ontstonden vrij snel horizontale relaties. De vluchtelingen hadden beperkte middelen en misten contact met de Nederlandse samenleving en kennis over activiteiten en gebruiken. Nijmegenaren nodigden bewoners van Heumensoord uit en via Facebook ontstonden sociale contacten. Zij zagen kans om gezamenlijk activiteiten buiten de poorten van COA te organiseren, zoals taal- en fietslessen, maar ook gezamenlijke etentjes in 
een klein gezelschap. Veel asielzoekers vonden het een verademing eens buiten de opvang te eten. De sociale media werden op zo'n manier gebruikt dat de communicatie zowel operationeel als veerkrachtgericht was. Communicatie via sociale media speelde in op de behoeften en het dagelijkse leven van de bewoners en onafhankelijke vrijwilligers uit Nijmegen. Deze sociale media verbonden beide groepen waarbij operationele en veerkrachtgerichte communicatie de boventoon voerde. Wat we hier zien is dat er zich parallel lopende communicatiepatronen manifesteren die nauwelijks bij elkaar komen.

Pas toen de vluchtelingen en mensen uit de lokale samenleving zich erin mengden, ontstond langzaam openheid om wat meer ruimte te creëren voor operationele veerkrachtgerichte communicatie. We zien dat terug in de communicatie via de ontmoeting en dialoog: in plaats van top-down een bottom-up aanpak. Bij het maken van netwerken - het leggen van verbindingen - is een zekere veerkracht noodzakelijk. De uitdaging van COA ligt in het zoeken naar samenwerking met andere partijen waarbij gezamenlijk oplossingen gezocht worden. Zo kan er meer ruimte geschapen worden voor communicatie die de veerkracht op een operationele en strategische wijze faciliteert.

Rondom asielzoekers hadden de (semi-)gouvernementele organisaties allemaal afzonderlijke taken, maar er was onvoldoende flexibiliteit - vooral niet in crisis, wanneer het juist nodig is - om buiten die kaders te voldoen aan de (basis)behoeften van de individuen. In deze 'gaten' in de netwerken, sprong de lokale bevolking, en soms ook een enkele professional en de vluchtelingen zelf in. Hierbij werden sociale media als belangrijk communicatiemiddel gebruikt.

De bijdrage van deze studie ten aanzien van eerder onderzoek is dat we laten zien dat verschillende soorten communicatie tussen de deelnemende partijen door elkaar heen lopen, elkaar aanvullen of soms beconcurreren. Deze dynamiek toont aan dat in de praktijk met een hoge concentratie aan sociale media-gebruik, niet meer iedereen afhankelijk is van een pushcultuur. Dat betekent ook dat crisisrespons en communicatie niet eenduidig zijn, maar dat de communicatiepatronen die ontstaan sterk afhankelijk zijn van de lokale context. Het vergt van (overheids)organisaties dat zij niet alleen informatie zenden vanuit hun klassieke kanalen, maar dat zij de doelgroepen ook moeten opzoeken op plekken waar zij zich (online) begeven. Op die manier kunnen zij effectiever (met een hoger bereik en snelheid) communiceren. Bovendien heeft deze studie laten zien dat een vluchteling/onderzoeker en een communicatie-professional/sociaal werker gezamenlijk via sociale media mogelijk maakten dat de leefomstandigheden 
van veel asielzoekers in deze noodopvang verbeterden. Later startten zij de stichting Yalla, waarmee zij hun verbindende, adviserende en informerende kracht voortzetten. Tegenwoordig werken ze samen met academici om alledaagse praktijken te verbinden met de wetenschap. Dit is een duidelijk voorbeeld van betrokken wetenschappelijk onderzoek.

\section{Referenties}

Alink, F., Boin, A., \& 't Hart, P. (2001). Institutional crises and reforms in policy sectors: the case of asylum policy in Europe. Journal of European Public Policy, 8(2), 286-3o6.

Buuren, A. van, Vink, M., \& Warner, J. (2016). Constructing Authoritative Answers to a Latent Crisis? Strategies of Puzzling, Powering and Framing in Dutch Climate Adaptation Practices Compared. Journal of Comparative Policy Analysis: Research and Practice, 18(1), 70-87.

Castells, M. (2015). Networks of outrage and hope. Social movements in the internet age. Cambridge: Polity.

COA (2016). COA gedragscode (Versiedatum 14-03-2016). Rijswijk: COA.

Coombs, W.T. (2007). Protecting Organization Reputations during a crisis. The development and application of situational crisis communication theory. Corporate Reputation Review, $10(3)$, $163^{-176 .}$

Dagevos, J. \& Odé, A. (2016). Gemeenten volop aan de slag met integratie statushouders. Socialisme \& Democratie, 73(4), 12-19.

De Beer, M. (2016). Redactioneel: Een ander geluid. Agora Magazine: 2.

Drabek, T.E. \& McEntire, D.A. (2003). Emergent phenomena and the sociology of disaster: lessons, trends and opportunities from the research literature. Disaster Prevention and Management: An International Journal, 12(2), 97-112.

Eriksson, M. \& Olsson, E.-K. (2016). Facebook and twitter in crisis communication: A comparative study of crisis communication professionals and citizens. Journal of Contingencies and Crisis Management, 24(4), 198-208.

Galindo, G. \& Batta, R. (2013). Review of recent developments in OR/MS research in disaster operations management. European Journal of Operational Research, 230, 201-211.

Gemeenteraad Nijmegen (2014). Samen voor Nijmegen: sociaal, duurzaam en ondernemend. Coalitieakkoord 2014-2018. SP-Groenlinks-De Nijmeegse fractie gesteund door VSP. Nijmegen: Gemeenteraad Nijmegen. URL: http://www2.nijmegen.nl/gemeente/ burgemeester_wethouder

Geuijen, K. (1998). Wonen en werken in een asielzoekerscentrum. Migrantenstudies, 14(4), 261-272.

Goffman, E. (2007). Asylums: Essays on the social situation of mental patients and other inmates. New Jersey: Aldine Transaction.

Henstra, D. (2010). Evaluating local government emergency management programs: what framework should public managers adopt? Public Administration Review, 70(2), 236-246.

Hadfield, A. \& Zwitter, A. (2015). Analyzing the EU refugee crisis: Humanity, heritage and responsibility to protect. Politics and Governance, 3(2), 129-134.

Holmes, S.M. \& Castañeda, H. (2016). Representing the 'European refugee crisis' in Germany and beyond. American Ethnologist, 43(1), 12-24.

Koca, B.T. (2016). New Social Movements: 'Refugees Welcome UK'. European Scientific Journal, 12(2), 96-108. 
Manso, M. \& Manso, B. (2012). The role of social media in crisis: A European holistic approach to the adoption of online and mobile communications in crisis response and search and rescue efforts, 17 th International Command \& Control Research \& Technology Symposium: Operationalising C2 Agility, Fairfax VA, 19-21 juni.

Meier, P. (2015). Digital humanitarians: How big data is changing the face of humanitarian response. London: Crc Press.

Olsson, E.-K. (2014) Crisis communication in public organisations: Dimensions of crisis communication revisited, Journal of Contingencies and Crisis Management, 22(2), 113-125.

Palen, L. (2008). Online social media in crisis events. Educause Quarterly, 31(3), 76-78.

Polakow-Suransky, S. (2016). The ruthlessly effective rebranding of Europe's new far right, The Guardian, 1 November.

Schmidt, A., Wolbers, J.J., Ferguson, J., \& Boersma, F.K. (verwacht). Are you Ready2Help? Conceptualizing the management of online and onsite volunteer convergence. Journal of Contingencies and Crisis Management.

Solnit, R. (2010). A paradise built in hell: The extraordinary communities that arise in disaster. London: Penguin.

Spindler, W. (2015). 2015: The Year of Europe's Refugee Crisis'. UNHCR-Tracks. Retrieved on, 5, 2016.

Treurniet, W., Messemaker, M., Wolbers, J., \& Boersma, F.K. (2015). Shaping the societal impact of emergencies: striking a balance between Control and Cooperation, International Journal of Emergency Services, 4(1), 129-151.

VluchtelingenWerk Nederland (2016, August 25). Cijfers. Retrieved from: http://www.vluchtelingenwerk.nl/feiten-cijfers/cijfers (Accessed on 10.12.2016).

\section{Over de auteurs}

PeerSmets is universitair docent bij de afdeling sociologie. Zijn onderzoeksbelangstelling gaat uit naar stedelijke woonomstandigheden in lage inkomensbuurten en burgerparticipatie. Hij heeft gepubliceerd over stedelijke segregatie, huisvesting, hypotheken, overheidsbureaucratie, burgertoppen en gemeenschappen en het dagelijks leven in buurten. Postadres: Vrije Universiteit, afdeling sociologie, De Boelelaan 1081, 1081 HV Amsterdam. E-mail: p.g.s.m.smets@vu.nl

Younes Younes is een nieuwkomer en onderzoeker bij de afdeling sociologie. Zijn belangstelling gaat uit naar in- en uitsluitingsmechanismen van de positie van vluchtelingen in Nederland. Hij heeft op Facebook lokale sites gemaakt van Refugees in the Netherlands en is mede oprichter van Yalla Foundation, een organisatie die streeft naar een insluitende samenleving (on- en offline). Postadres: Vrije Universiteit, afdeling sociologie, De Boelelaan 1081, 1081 HV Amsterdam.

E-mail:Y.Younes@vu.nl 
Marinka Dohmen is communicatie- en beleidsadviseur en heeft samen met nieuwkomers Yalla (zie www.yallafoundation.nl) en Refugees in The Netherlands opgezet. Zij is volop bezig om nieuwkomers via online communities te informeren, bruggen te bouwen en wederzijdse contacten te stimuleren en aan te jagen. Als doelgroepenspecialist zorgt ze ervoor dat zoveel mogelijk mensen mee kunnen doen in onze steeds ingewikkelder wordende samenleving. Postadres: Allesbinder, Weurtseweg 150, 6541 BA Nijmegen.

E-mail: marinka@yallafoundation.nl

Kees Boersma is universitair hoofddocent bij de afdeling Organisatiewetenschappen. Hij doet onderzoek naar de organisatie en governance van rampenbestrijding in binnen en buitenland. Hij geeft leiding aan het NWO project Enhancing Smart Disaster Governance. Meer details zijn te vinden op zijn website: www.keesboersma.com Postadres: Vrije Universiteit, afdeling organisatiewetenschappen, De Boelelaan 1081, 1081 HV Amsterdam. E-mail: F.K.Boersma@vu.nl

Lenie Brouwer is universitair docent bij de afdeling Sociale en Culturele Antropologie van de Vrije Universiteit. Zij houdt zich bezig met de thema's: migratie, gender, Islam en Marokko. Postadres: Vrije Universiteit, afdeling sociale en culturele antropologie, De Boelelaan 1081, 1081 HV Amsterdam. E-mail: L.A.Brouwer@vu.nl 